\title{
Hypertrophic anterior choroidal artery: images and brief embryological overview
}

\author{
Deep Das (D) , ${ }^{1}$ Rahul Kumar, ${ }^{2}$ Arpan Dutta (D) ${ }^{1}$
}

${ }^{1}$ Neurology, Institute of Postgraduate Medical Education and Research Bangur Institute of Neurology, Kolkata, West Bengal, India

${ }^{2}$ Neurology, G S Neuroscience Clinic and Research Centre Pvt, Patna, Bihar, India

\section{Correspondence to}

Dr Deep Das:

deepdas1974@gmail.com

Accepted 12 December 2020

\section{DESCRIPTION}

During the embryological stage of humans when the vertebrobasilar system has not been developed fully, the cortical regions of the temporal, parietal and occipital lobes are supplied by the anterior choroidal artery (AChA). ${ }^{1}$ Once the vertebrobasilar system develops, this territory is gradually taken over by the posterior cerebral artery (PCA). ${ }^{1}$ However, in some cases, AChA continues to supply these regions. ${ }^{12}$ More commonly, the territory supplied by the inferior temporal branch of PCA is captured by the AChA. ${ }^{2}$ These cases are often misinterpreted as duplicated posterior communicating artery (PComA) or duplicated AChA. Rarely, the entire cortical territory of the PCA is supplied by the AChA. ${ }^{2}$ The PComA-PCA system is usually hypoplastic in such cases, but rarely can
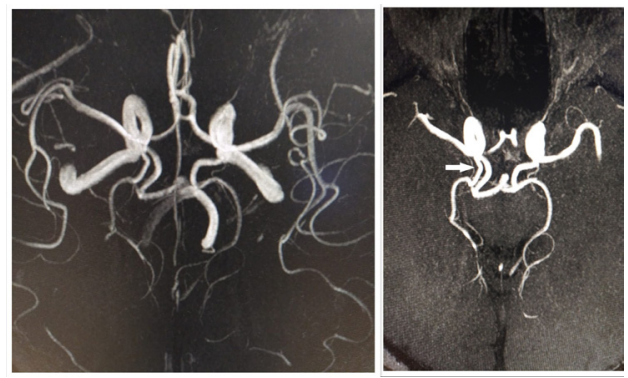

Figure 1 Collage depicting the hypertrophied right anterior choroidal artery, anteroposterior view (left) and axial reconstruction of source images of time of flight sequences with the artery marked out with a solid arrowhead (right) view.

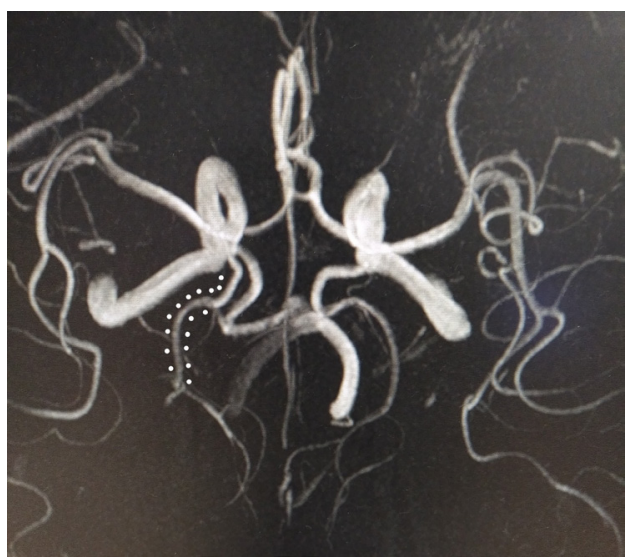

Figure 2 The hypertrophied right anterior choroidal artery course has been marked out with white dots. be prominent again giving the false impression of a duplicated PComA. ${ }^{2}$ Connection between the AChA and the PComA-PCA system can also be present. ${ }^{2}$ Here is the MR angiography images of a 30-year-old man, who presented with migrainous headache and underwent routine imaging. On the left side, a fetal origin of PCA is visible. (figure 1) On the right side, the PComA and the P1 segment of the right PCA are well developed, but the right PCA territory distal to the P1 segment is entirely annexed by the right AChA (figures 1 and 2). There is a connection between the right AChA and the right PCA just distal to the P1 segment. This type of anatomical variants should not be misidentified as a duplicated PComA because embryologically there can be only one PComA and only one AChA.

\section{Learning points}

- The anterior choroidal artery can sometimes retain its embryological cortical territory, partially or completely, which is usually annexed by the developing posterior cerebral artery in the developing embryo.

- Proper identification of the anatomical variants of the anterior choroidal artery is necessary to avoid misinterpretations.

Acknowledgements Professor Biman Kanti Roy MD, DM. Dr Soumitro Bhattacharya MD. Dr Subhadeep Gupta MD. Dr Amlan Kusum Dutta MD.

Contributors All authors have actively contributed, performed manuscript preparation and research which has gone into the final submitted version.

Funding The authors have not declared a specific grant for this research from any funding agency in the public, commercial or not-for-profit sectors.

Competing interests None declared.

Patient consent for publication Obtained.

Provenance and peer review Not commissioned; externally peer reviewed.

\section{ORCID iDs}

Deep Das http://orcid.org/0000-0003-1948-9136

Arpan Dutta http://orcid.org/0000-0001-6685-5739

\section{REFERENCES}

1 Abrahams JM, Hurst RW, Bagley LJ, et al. Anterior choroidal artery supply to the posterior cerebral artery distribution: embryological basis and clinical implications. Neurosurgery 1999;44:1308-14.

2 Takahashi S, Suga T, Kawata Y, et al. Anterior choroidal artery: angiographic analysis of variations and anomalies. AJNR Am J Neuroradiol 1990;11:719-29. 
Copyright 2021 BMJ Publishing Group. All rights reserved. For permission to reuse any of this content visit https://www.bmj.com/company/products-services/rights-and-licensing/permissions/

BMJ Case Report Fellows may re-use this article for personal use and teaching without any further permission.

Become a Fellow of BMJ Case Reports today and you can:

- Submit as many cases as you like

- Enjoy fast sympathetic peer review and rapid publication of accepted articles

Access all the published articles

Re-use any of the published material for personal use and teaching without further permission

Customer Service

If you have any further queries about your subscription, please contact our customer services team on +44 (0) 2071111105 or via email at support@bmj.com.

Visit casereports.bmj.com for more articles like this and to become a Fellow 